\title{
METHANE MITIGATION POSSIBILITIES AND WEIGHT GAIN IN CALVES FED WITH PREBIOTIC INULIN
}

\author{
Sintija Jonova, Aija Ilgaza, Inga Grinfelde \\ Latvia University of Agriculture \\ sintija.gorodko@llu.lv
}

\begin{abstract}
Methane is considered to be the main greenhouse gas (GHG) emitted by livestock. One method for reducing methane emissions from ruminants is to improve production efficiency, which reduces methane emissions per unit of product (FAO, 2010; Gworgwor, Mbahi, \& Yakubu, 2006). There are many researches about prebiotics which can reduce methane production in livestock, for example, galacto-oligosaccharides reduced methane emission up to $11 \%$ (liters/ day) (Zhou et al., 2004). There is almost no information about prebiotic inulin, so the aim of this research was to determine the impact of different dosages of inulin concentrate $(50 \%)$ on the increase of calves' body weight and its impact on methane emission, as well as to find out how the results change if it is added to barley flour not to milk as in our previous research. Approximately fifty days old, clinically healthy, different Holstein Friesian crossbreed calves kept in groups of 8 , in a partly closed space with a natural ventilation through windows were included in this research. Eight calves were in the control group $(\mathrm{CoG})$ and sixteen received inulin $(\operatorname{Pre} 12(\mathrm{n}=8)$, Pre24 $(\mathrm{n}=8))$. At the beginning of the experiment - the $28^{\text {th }}$ and $56^{\text {th }}$ day - we determined each calf's weight and measured the methane level in the rumen by using the PICARROG-2508 gas analyser (Fleck, 2013). We concluded that inulin supplement significantly $(\mathrm{p} \leq 0.05)$ increased the live weight gain comparing Pre 24 and $\mathrm{CoG}$. The highest methane production on $1 \mathrm{~kg}$ of body weight at the end of the research was detected in Pre24-1.24 $\mathrm{mg} \mathrm{m}^{-3}$ and the lowest in CoG -0.99 $\mathrm{mg} \mathrm{m}^{-3}$.
\end{abstract}

Key words: calves, greenhouse gas emission, inulin, weight gain.

\section{Introduction}

Climate changes come along with new challenges that are critical in agricultural production both in Latvia and the whole world. After regaining independence, Latvia takes an active part in reducing the negative climate changes in the world. However, since the year 2005 due to the rise of economic activities in Latvia, the greenhouse gas (GHG) production in the agricultural sector shows a progressive tendency, furthermore, the agricultural sector is the second largest source of GHG, creating $20 \%$ of all GHG in the country. (Bērzinga et al., 2014) According to the collected GHG data about the situation in Latvia in the agricultural sector, the main sources of GHG are: 1) agricultural soil management nitric oxide $\left.\left(\mathrm{N}_{2} \mathrm{O}\right) ; 2\right)$ ruminant enteric fermentation where methane $\left(\mathrm{CH}_{4}\right)$ is produced due to biological food processing and fermentative processes; 3) methane $\left(\mathrm{CH}_{4}\right)$ and nitric oxide $\left(\mathrm{N}_{2} \mathrm{O}\right)$ production from manure (Bērziņa et al., 2014; Ilgaza et al., 2016).

Globally, $50-60 \%$ of methane emissions are from the agricultural sector, specifically from livestock production operations; the principal source of methane is from ruminant animals (McMichael et al., 2007). Digestive processes happen mainly in anaerobic conditions, and microorganisms have a huge role in these processes. Enteric fermentation from livestock is a large source of methane, which has a global warming potential 23 times of carbon dioxide (Bhatta et al., 2007; Loh et al., 2008). The ruminant stomach consists of 4 compartments and the rumen is the main place of methane production. Approximately $90 \%$ of the whole methane are produced there, the rest of it is produced in the large intestines. Almost all methane $(89 \%)$ emitted from ruminants is produced in the rumen and exhaled through the mouth and nose (Murray et al., 1999).

One way of decreasing GHG is to use a specific methane inhibitor 3NOP (3-nitrooxypropanol) that has no significant impact on cows: feed intake, fibre digestibility and milk production. Reseachers have also noticed the increase in milk protein and lactose level in milk. The emitted methane was reduced by $30 \%$ (Hristov et al., 2015). In other studies, researchers reached the methane reduction by $20 \%$, at the same time, the weight gain increased by additional $75 \mathrm{~g} /$ day, and milk yield increased by $11 /$ day in dairy cattle (Bruinenberg et al., 2002; Ilgaza et al., 2016; Nkrumah et al., 2006). It means that with a significant reduction of $\mathrm{CH}_{4}$ emission the animal productivity can be improved, but we need to find the optimal feeding recipe which would be compatible with conditions and available feed sources in Latvia, taking into account economic factors and the obtained production. The other way to decrease GHG is to reduce the use of dairy cattle for beef production. Therefore, it is advisable to slaughter those calves which are not used for herd reproduction before they have become full ruminants, that is - before the emission of gases from the rumen into the surrounding environment has not significantly increased. However, producers in order to get more valuable production from one animal grow animals longer till they reach a higher live weight. We consider that a shorter animal growing period can be achieved by making corrections in the animal feeding strategy and by using natural feed supplements which 
can promote animal interior body reserve usage. Prebiotics can increase daily weight gain in calves and are used along with nitrate, probiotics, and yeasts and have a potential to reduce methane production (Mwenya et al., 2004; Hasunuma et al., 2011; Ilgaza et al., 2016). Such prebiotics as fructo-oligosaccharides (FOS), inulin and galacto-oligosaccharides (GOS) can be used to reduce methane production in ruminants (Zhou et al., 2004; Charalampopoulos \& Rastall, 2009). But there are fewer studies done about FOS and inulin (both are components of Jerusalem artichoke) and their impact on methane reduction in ruminants (Roonal, 2015), therefore we used inulin for our research. In the previous study by Ilgaza et al. (2016), milk supplementation with inulin had very promising results regarding weight gain when animals in the experimental group reached $90 \mathrm{~kg}$ weight 3 weeks earlier than the control group; also the live weight gain was higher in calves fed with additional supplement of inulin.

In newborn ruminants the oesophageal groove is present. It is a channel that takes milk from the oesophagus into the abomasum, bypassing the rumen, reticulum and omasum. Oesophageal groove practically disappears in the fifth month of the calf's life (Millen et al., 2016).

In this research, the way of inulin supplementation was changed to see if the results differ from our previous study. If inulin is added to fodder, it passes directly to the rumen and not abomasum because the oesophageal groove facilitates only the movement of liquid. The aim of this study was to repeat the research with inulin and evaluate how it impacts weight gain in a dairy farm of intensive production by using two doses of inulin added to barley flour which showed the best results in the previous research, and also how this inulin supplementation impacts methane production in calves' rumen.

\section{Materials and Methods}

The research was conducted with clinically healthy different Holstein Friesian crossbreed calves. Their average age was $49 \pm 10$ days and average weight was $79.6 \pm 12.82 \mathrm{~kg}$. They were kept in groups of 8 calves in a partly closed space with a natural ventilation through windows. Before the research, they all had received the same feed and were kept in the same conditions.

Eight calves were in the control group ( $\mathrm{CoG})$ and sixteen were fed with an additional prebiotic - specially produced flour of Jerusalem artichoke, organized in groups Pre12 $(n=8)$, Pre24 $(n=8)$. The study included prebiotic inulin concentrate flour of Jerusalem artichoke $(50 \%)$ produced in Latvia by using special technologies. The flour of Jerusalem artichoke usually contains $10 \%$ of inulin, but it is possible to increase its amount up to $48.5 \%-50 \%$ (Fleming et al., 1979; Valdovska et al., 2012; Ilgaza et al., 2016). Calves from group Pre12 were fed with additional $12 \mathrm{~g}$ flour of Jerusalem artichoke (containing $6 \mathrm{~g}$ of inulin), group Pre $24-24 \mathrm{~g}$ of flour (containing $12 \mathrm{~g}$ of inulin). The prebiotic was added to barley flour once a day in the evenings. All calves had free access to water and hay and they also got whole milk and a calf starter meal (Ilgaza et al., 2016).

The length of the research was 56 days. On the $1^{\text {st }}$, $28^{\text {th }}$ and $56^{\text {th }}$ day we determined each calf's weight by using the weight measuring tape and determined the amount of methane in the rumen by using a mobile PICARROG-2508 gas analyser (Fleck, 2013). We acquired the gas from the rumen by puncturing it through the abdominal wall by using a $14 \mathrm{G}$ needle and a $20 \mathrm{ml}$ syringe. The gas was evaluated as soon as it was obtained to reduce the possibility that it can mix with the surrounding air. For statistical analysis of all obtained data we used the computer programme MS Excel 2013. The analysis was conducted by applying the statistical methods to calculate mean values and

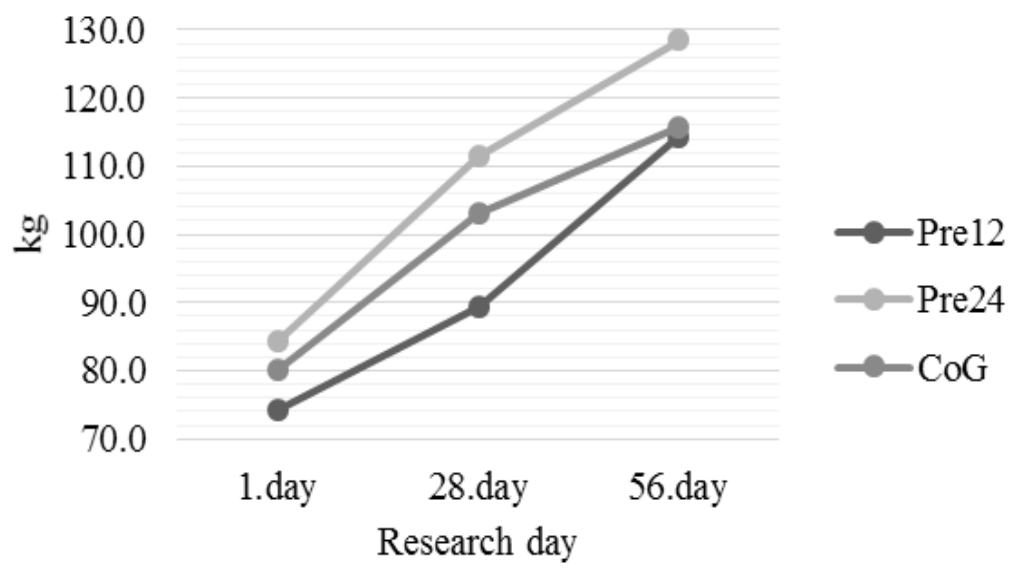

Figure 1. The increase of live weight of calves during the research. 


\section{Growth Performance of Calves}

\begin{tabular}{|c|c|c|c|c|}
\hline Groups & $\begin{array}{c}\text { Average live weight gain } \\
(\mathrm{kg} \text { and \%), } \\
1^{\text {st }}-28^{\text {th }} \text { research day }\end{array}$ & $\begin{array}{c}\text { Average live weight gain } \\
\left(\mathrm{kg} \text { and \%), } 28^{\text {th }}-56^{\text {th }}\right. \\
\text { research day }\end{array}$ & $\begin{array}{c}\text { Average live weight gain } \\
(\mathrm{kg} \text { and \%), } \\
1^{\text {st }}-56^{\text {th }} \text { research day }\end{array}$ & $\begin{array}{c}\text { Average daily } \\
\text { weight gain } \\
\left(\mathrm{kg} \mathrm{d}^{-1}\right)\end{array}$ \\
\hline CoG & $22.9 \pm 3.80(+28.4 \%)$ & $12.5 \pm 9.77(+12.1 \%)$ & $35.4 \pm 7.73(+44.0 \%)$ & $0.6 \pm 0.14$ \\
\hline Pre12 & $15.1 \pm 4.19(+20.3 \%)$ & $24.9 \pm 6.92(+27.8 \%)$ & $40 \pm 6.39(+53.8 \%)$ & $0.7 \pm 0.11$ \\
\hline Pre24 & $27.4 \pm 10.60(+32.4 \%)$ & $16.8 \pm 6.36(+15.1 \%)$ & $44.1 \pm 11.15(+52.3 \%)$ & $0.8 \pm 0.20$ \\
\hline
\end{tabular}

standard deviation. The significance was determined by the t-test; $\mathrm{p} \leq 0.05$ means that difference is significant.

\section{Results and Discussion}

Our first aim of this research was to find out if the inulin supplement, which is added to barley flour, can speed up the growth rate of calves. On the first day of the research, the median weight of all calves was without significant ( $p$ value $>0.05$ ) differences. On the $28^{\text {th }}$ day of the research, the median weight of Pre12 calves was significantly lower $(p \leq 0.01)$ than the median weight of Pre24 calves $(89.5 \pm 7.29 \mathrm{~kg}$ and $111.6 \pm 19.91 \mathrm{~kg}$, respectively) (Fig. 1).

On the $28^{\text {th }}$ day of the research, the median weight of Pre12 calves was lower than in CoG calves. We cannot explain this slower weight gain in group Pre12, but it could be due to some health problems like diarrhoea and respiratory diseases as these problems occurred time after time in calves during the research. On the $56^{\text {th }}$ day of the research, the median weights between the groups were very similar, in Pre12 it was $114.4 \pm 12.37 \mathrm{~kg}$ and in $\mathrm{CoG}-115.6 \pm 7.11 \mathrm{~kg}$. The final weight of Pre12 was similar to $\mathrm{CoG}$ weight because of better daily weight gain, and the prebiotic could positively impact this increase of daily weight in Pre12.

At the end of the research, on the $56^{\text {th }}$ day, there was a significant difference in the average weight between Pre12 and Pre24 $(\mathrm{p} \leq 0.05)$, as well as between Pre24 and $\mathrm{CoG}(\mathrm{p} \leq 0.05)$ (respectively $114.4 \pm 12.37 \mathrm{~kg}$; $128.4 \pm 18.8 \mathrm{~kg}$ and $128.4 \pm 18.8 \mathrm{~kg} ; 115.6 \pm 7.11 \mathrm{~kg}$ ).

It was essential to determine the average live weight gain in each period of our research $\left(1^{\text {st }}-28^{\text {th }}\right.$ day; $28^{\text {th }}-56^{\text {th }}$ day and $1^{\text {st }}-56^{\text {th }}$ day). The results in kilograms and percentages are summarized in Table 1.

There was a significant difference in the average live weight gain between Pre12 and Pre24 and between Pre12 and CoG in both research periods: $1^{\text {st }}$ $28^{\text {th }}$ day $(\mathrm{p} \leq 0.01)$ and $28^{\text {th }}-56^{\text {th }}$ day $(\mathrm{p} \leq 0.05)$. The average live weight gain at the end of the research was the highest in Pre24 $(44.1 \pm 11.15 \mathrm{~kg})$, but the lowest in CoG $(35.4 \pm 7.73 \mathrm{~kg})$. The increase of the live weigh expressed in percentage at the end of the research was in $\mathrm{CoG}-44.0 \%$, in Pre $12-53.8 \%$ and in
Pre24 - 52.3\%. We can conclude that groups fed with inulin supplement showed much better increase of the live weight compared to the control group. These results conform to the results of other researchers who found that inclusion of inulin in the milk replacer of pre-ruminant calves leads to significantly higher live weight gains and better faecal consistency (Kaufhold $e t$ al., 2000; Verdonk \&Van Leeuwen, 2004).

The foregut and hindgut houses millions of diverse groups of microflora, namely, bacteria, fungi, yeasts, phage particles, archaea etc. Prebiotics are fermented by a number of rumen bacteria for its utilization as a source of energy (Öztürk, 2008; Kaufhold et al., 2000; Cota \&Whitefield, 1998; Samanta et al., 2013). Also anaerobic fungi (Neocallimastix stains) can metabolize inulin in the rumen (Fonty, 1991).

The lowest average daily weight gain was noticed in $\mathrm{CoG}\left(0.6 \pm 0.14 \mathrm{~kg} \mathrm{~d}^{-1}\right)$. It was higher in groups fed with inulin supplement, in group Pre12 $0.7 \pm 0.11 \mathrm{~kg}$ $\mathrm{d}^{-1}$ and in group Pre24 $0.8 \pm 0.20 \mathrm{~kg} \mathrm{~d}^{-1}$, respectively. The results of t-test showed that calves of group Pre24 fed with $24 \mathrm{~g}$ of prebiotics did not give a significantly higher average daily weight gain compared to group Pre12 (12 g of prebiotics) and CoG. Our results showed that the double dose of inulin did not give a significantly higher average daily weight gain.

In the study by Ilgaza et al. (2016) where inulin was added to milk (12 $\mathrm{g}$ and $24 \mathrm{~g}$ ), the results showed that inulin increased the average daily weight gain. The highest average live weight gain during the whole study was in Pre24 group, and similar results were obtained also in this experiment.

Our second aim of this research was to determine if inulin supplement reduces methane production. We set this aim because many researchers have investigated the possible impact of prebiotics on reducing GHE. For example, the administration of galacto-oligosaccharides (GOS) supplementation decreased nitrite accumulation in the rumen and plasma and nitrate-induced methaemoglobin, while retaining low methane production. $11 \%$ reduction in methane emission (litres/day) in GOS supplemented diet compared to the control diet has been reported (Zhou et al., 2004). Other research also indicates that GOS are efficacious in reducing methane production in 


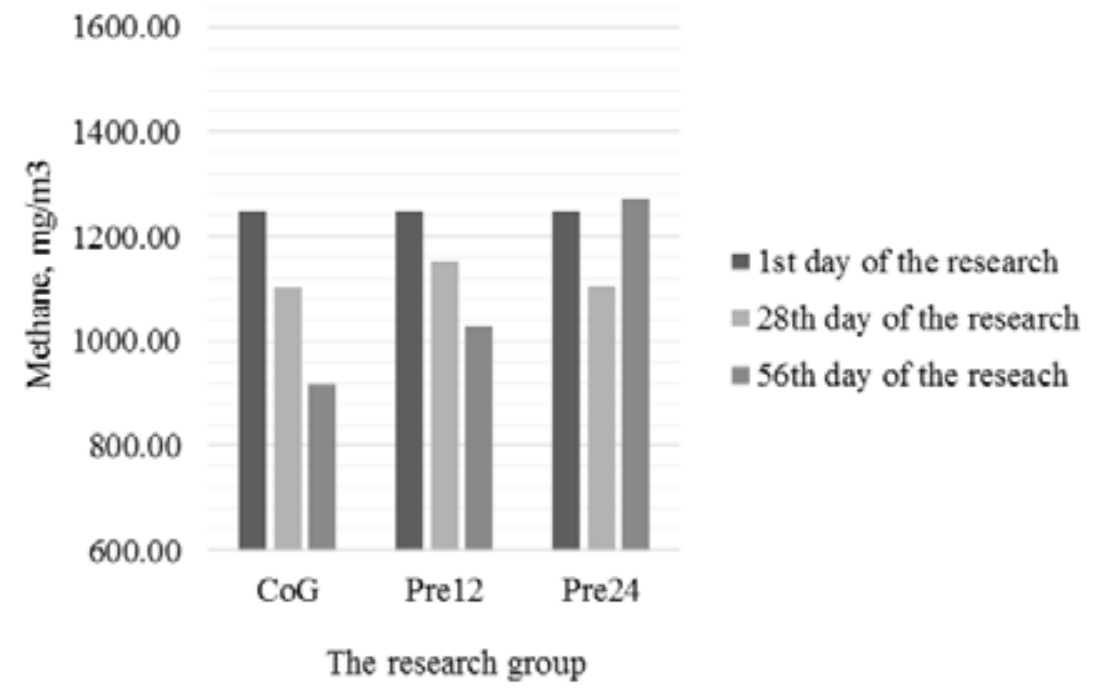

Figure 2. The concentration of methane in the rumen by groups during the whole research.

dairy cows. Supplementation of dairy cows with GOS resulted in an $11 \%$ reduction in methane production (Charalampopoulos \& Rastall, 2009). Inulin, FOS and GOS are called prebiotics and can reduce methane production, but there are fewer studies done about inulin and FOS (both are components of Jerusalem artichoke) and their impact on methane reduction in ruminants (Roonal, 2015), therefore we used inulin for our research. To reduce greenhouse gas emission, researchers also propose to shorten the period of breeding calves of dairy breeds (Mirzaei-Aghsaghali et al., 2015; FAO, 2010; Ilgaza et al., 2016).

In our research, we noticed that in CoG calves the median amount of methane in the rumen showed a tendency to get lower, and the same process was noticed in calves of group Pre12, while in group Pre24 the methane concentration in the rumen at the end of the research increased (Fig. 2).

The amount of methane in the calves' rumen at the end of the research in group Pre24 was the highest $1,273.0 \pm 317.60 \mathrm{mg} \mathrm{m}^{-3}$, but in group CoG the lowest $-917.5 \pm 217.30 \mathrm{mg} \mathrm{m}^{-3}$. By using t-test we found out that this difference was significant ( $p$ $\leq 0.05$ ). We can conclude that feeding the chosen concentrations of inulin supplement promote the production of methane in the rumen. This did not match to our thoughts and to results of some other authors about inulin and FOS that these prebiotics can reduce methane production in ruminants (Zhou et al., 2004; Charalampopoulos \& Rastall, 2009; Roonal, 2015). The efficiency of prebiotics of other group (GOS) has been proved in many studies mentioned before. More research is needed about inulin and FOS and their possible impact on reduction of methane emission in ruminants.

The highest methane production on $1 \mathrm{~kg}$ body weight at the end of the research on day 56 was noticed in Pre24 - $1.24 \mathrm{mg} \mathrm{m}^{-3}$, less in Pre12 - $1.12 \mathrm{mg} \mathrm{m}^{-3}$, and the lowest it was in $\mathrm{CoG}-0.99 \mathrm{mg} \mathrm{m}^{-3}$.

Although other authors have reported that prebiotics can impact methane production by lowering it, we did not find any reduction of methane production in the rumen in calves fed with barley flour and inulin (Zhou et al., 2004; Charalampopoulos \& Rastall, 2009). We noticed that the higher the dose of inulin, the higher the methane production on $1 \mathrm{~kg}$ of body weight.

Our next aim is to repeat the research in one farm with calves which receive inulin with whole milk and calves which receive this prebiotic with fodder, and to compare the results since in these feeding strategies inulin gets into different stomach compartments.

\section{Conclusions}

1. Calves of group Pre24 fed with $24 \mathrm{~g}$ of prebiotics did not show a significantly higher average daily weight gain in comparison with Pre12 (12 g of prebiotics) and CoG. But at the end of the research, on the $56^{\text {th }}$ day there was a significant difference in the average weight between Pre12 and Pre24 ( $p$ $\leq 0.05)$, as well as between Pre 24 and CoG ( $\mathrm{p} \leq$ $0.05)$.

2. The amount of methane in the calves' rumen at the end of the research was the highest in group Pre24 $-1,273.0 \pm 317.60 \mathrm{mg} \mathrm{m}^{-3}$, but the lowest in group $\mathrm{CoG}-917.5 \pm 217.30 \mathrm{mg} \mathrm{m}^{-3}$; this difference was significant $(\mathrm{p} \leq 0.05)$. We can conclude that feeding the chosen concentrations of inulin supplement promote the production of methane in the rumen.

3. The highest methane production on $1 \mathrm{~kg}$ body weight at the end of the research was found in Pre24, but the lowest was in CoG, so the higher the chosen concentration of inulin, the higher the methane production on $1 \mathrm{~kg}$ of body weight. 


\section{Acknowledgements}

This research has been supported by the National

Research Programme Agricultural Resources for
Sustainable Production of Qualitative and Healthy Foods in Latvia (AgroBioRes) (2014 - 2017).

\section{References}

1. Bērziņa, L., Sudārs, R., Priekulis, J., \& Baranovska, E. (2014). Pētījuma 'Siltumnīcefekta gāzu emisiju aprēķinu veikšana lauksaimniecības sektorā par 2012.gadu' atskaite (Research 'Calculations of greenhouse gas emission in agricultural sector about year 2012’ report). LLU. (in Latvian).

2. Bhatta, R., Nishi, B., \& Kurihara, O. (2007). Measurement of Methane Production from Ruminants. AsianAustralian Journal of Animal Science, vol. 20 (8), 1305 - 1318. DOI: 10.5713/ajas.2007.1305.

3. Bruinenberg, M.H., van der Honing, Y., Agnew, R.E., Yan, T., van Vuuren, A.M., \& Valk, H. (2002). Energy metabolism of dairy cows fed on grass. Livestock Production Science, 75(2), 117 - 128. DOI: 10.1016/S0301-6226(01)00306-2.

4. Charalampopoulos, D., Rastall, R.A. (2009). Prebiotics and Probiotics. Science and Technology. Springer, Vol. 1, $1146-1148$

5. Cota, M.A., Whitefield, T.R. (1998). Xylooligosaccharides utilization by ruminal anaerobic bacterium Selemonas ruminantium. Current Microbiology. 36(4), 183-189. DOI: 10.1007/s002849900291.

6. FAO (2010). Greenhouse Gas Emissions from the Dairy Sector: A Life Cycle Assessment. Food and Agriculture Organization of the United Nations, Rome, Italy

7. Fleck, D., He, Y., Alexander, C., Jacobson, G. \& Cunningham, K. (2013). Simultaneous soil flux measurements of five gases $-\mathrm{N}_{2} \mathrm{O}, \mathrm{CH}_{4}, \mathrm{CO}_{2}, \mathrm{NH}_{3}$, and $\mathrm{H}_{2} \mathrm{O}-$ with the Picarro G2508. Picarro Appl. Note AN034.

8. Fleming, S., Groot, W.J. (1979). Preparation of high-fructose syrup from the tubers of the Jerusalem artichoke (Helianthus tuberosus). CRC Critical reviews in Food Science and Nutrition, 12 (1), pp. 1 - 28.

9. Fonty, G. (1991). The rumen anaerobic fungi. In Jouany J.P. (Ed.), Rumen microbial metabolism and ruminant digestion (pp. 53 - 70). Paris: INRA Editions.

10. Gworgwor, Z.A., Mbahi, T.F., \& Yakubu, B. (2006). Environmental implications of methane production by ruminants: A review. Journal of Sustainable Development in Agriculture and Environment 2, 1 - 14.

11. Hasunuma, T., Kawashima, K., Nakayama, H., Murakami, T., Kanagawa, H., Ishii, T., Akiyama, K., Yasuda, K., Terada, F., \& Kushibiki, S. (2011). Effect of cellooligosaccharide or synbiotic feeding on growth performance, fecal condition and hormone concentrations in holstein calves. Animal Science Journal 82(4), 543 - 548. DOI: 10.1111/j.1740-0929.2010.00861.x.

12. Hristov, A.N., Joonpyo, Oh, Giallongo, F., Frederick, W.T., Harper, T.M., Weeks, L.H., Branco, A.F., Moate, J.P., Deighton, H.M., Williams, R.O., Kindermann, M., \& Duvale, S. (2015). An inhibitor persistently decreased enteric methane emission from dairy cows with no negative effect on milk production, Proc Natl Acad Sci U S A, 2015 Aug 25; 112(34), 10663 - 10668. DOI: 10.1073/pnas.1504124112.

13. Ilgaza, A., Arne, A., Gorodko, S., \& Ilgazs, A. (2016). Impact of inulin on calves' growth and possible reduction of greenhouse gas emission. AGROFOR International Journal. 1(2), 88 - 94. DOI: 10.7251/ AGRENG1602088I.

14. Kaufhold, J., Hammon, H.M., Blum, J.W. (2000). Fructooligosaccharides supplementation effects on metabolic, endocrine and hematological traits in veal calves. J Vet Med A. 47(1), 17 - 29. DOI: 10.1046/j.1439-0442.2000.00257.x.

15. Loh, Z., Chen, D., Bai, M., Naylor, T., Griffith, D., Hill, J., Denmead, T., McGinn, S., \& Edis, R. (2008). Measurement of Greenhouse Gas Emissions From Australian Feedlot Beef Production Using Open-Path Spectroscopy and Atmospheric Dispersion Modeling. Australian Journal of Experimental Agriculture. 48(2), 244 - 247. DOI: 10.1071/EA07244.

16. McMichael, A.J., Powles, J.W., Butler C.D., \& Uauy, R. (2007). Food, livestock production, energy, climate change, and health. The Lancet. 370(9594), 1253 - 1263. DOI: 10.1016/S0140-6736(07)61256-2.

17. Membrive, C.M.B. (2016). Anatomy and Physiology of the Rumen. In Millen, D.D., Arrigoni, M. de Beni, \& Pacheco, R. Dias L. (Eds.), Rumenology (pp. 1 - 38). Switzerland: Springer International Publishing.

18. Mirzaei-Aghsaghali, A., Maheri-Sis, N., Alireza Siadati, S., \& Jalilnejad, N. (2015). Factors Affecting Mitigation of Methane Emission from Ruminants: Management Strategies. ECOLOGIA BALKANICA. $7(1), 171-190$.

19. Murray, P.J., Moss, A., Lockyer, D.R., \& Jarvis, S.C. (1999). A Comparison of Systems for Measuring Methane Emissions from Sheep. Journal of Agricultural Science 133, 439 - 444. DOI: 10.1017/ S0021859699007182. 
20. Mwenya, B., Santoso, B., Sar, C., Gamo, Y., Kobayashi, T., Arai, I., \& Takahashi, J. (2004). Effects of including $\beta 1-4$ galacto-oligosaccharides lactic acid bacteria or yeast culture on methanogenesis as well as energy and nitrogen metabolism in sheep. Animal Feed Science and Technology. 115(3-4), 313 - 326. DOI: 10.1016/j.anifeedsci.2004.03.007.

21. Nkrumah, J.D., Okine, E.K., Mathison, G.W., Schmid, K., Li, C., Basarab, J.A., Price, M. A., Wang, Z., \& Moore, S.S. (2006). Relationships of feedlot feed efficiency, performance, and feeding behavior with metabolic rate, methane production, and energy partitioning in beef cattle. Journal of Animal Science. 84(1), 145 - 153. DOI: $10.2527 / 2006.841145 x$.

22. Öztürk, H. (2008). Effects of inulin on rumen metabolism in vitro. Veterinary Journal of Ankara University. 55(2), 103 - 106. DOI: 10.1501/Vetfak_0000000302.

23. Roonal, P.K. (2015). Use of feed additives for reducing greenhouse gas emissions from dairy farms. Microbiology Research. 6(1), 19 - 25. DOI: 10.4081/mr.2015.6120.

24. Samanta, A.K., Jayapal, N., Senani, S., Kolte, A.P., \& Sridhar, Manpal, Bhatta, R. (2013). Prebiotic inulin: Useful dietary adjuncts to manipulate the livestock gut microflora. Brazilian Journal of Microbiology. 44(1), 1 - 14. DOI: 10.1590/S1517-83822013005000023.

25. Valdovska, A., Jemeljanovs, A., Zītare, I., Krastiņa, V., Pilmane, M., \& Proškina, L. (2012). Impact of prebiotic on chicken digestive tract morphofunctional status. In: Conference on Current events in veterinary research and practice, LLU, Jelgava, pp. $63-67$.

26. Verdonk, J.M.A.J., \& Van Leeuwen, P. (2004). The application of inulin type fructans in diets for veal calves and broilers. Inulin and Oligofructose Feed Good Factors for Health and Well Being; 4th Orafti Research Conference; Paris.

27. Zhou, X., Sar, C., Kobayashi, T., Takahashi, J., Santoso, B., Gamo, Y., \& Mwenya, B. (2004). Effects of probiotic-vitacogen and B1-4 galacto-oligosaccharides supplementation on methanogenesis and energy and nitrogen utilization in dairy cows. Asian-Australasian Journal of Animal Sciences. 17(3), 349 - 354. DOI: 10.5713/ajas.2004.349. 